\section{MAJ}

33,3

\section{8}

\title{
Factors affecting the voluntary use of internal audit: evidence from the UK
}

\author{
Hazem Ramadan Ismael \\ Accounting and Information Systems Department, Qatar University, \\ Doha, Qatar, and \\ Clare Roberts \\ Business School, University of Aberdeen, Aberdeen, UK
}

\begin{abstract}
Purpose - This study aims to identify the factors that lead non-financial companies listed in the UK to use an internal audit function (IAF) as a monitoring mechanism. Although the use of an IAF in the UK is voluntary, no prior research has examined the drivers for using one.

Design/methodology/approach - Financial and non-financial data were collected from the annual reports of 332 UK non-financial companies listed on the London Stock Exchange (LSE) Main Market. Univariate tests and multivariate logistic regression tests were used to test the research hypotheses. A theoretical framework based on both agency theory and transaction cost economics (TCE) theory was used to explain the economic factors affecting the use of an IAF.
\end{abstract}

Findings - The study provides evidence that firm size, level of internal risks, agency problem between owners and managers and existence of an effective audit committee are associated with the existence of an IAF. Thus, the need to have strong internal control and risk management systems and to reduce both internal and external agency costs drives companies to have an IAF. These results suggest the importance of IAF as an internal corporate governance tool and the effectiveness of UK governance regulations in monitoring the effectiveness of internal control systems.

Practical implications - Given the importance of the IAF's corporate governance role, the study provides some policy implications. Regulators should pay more attention to the issue of maintaining an IAF, especially by large companies, the relationship between the IAF and other governance parties, especially the audit committee, and the disclosure of more relevant information about the IAF's characteristics and practices.

Originality/value - This is the first study to examine the factors affecting the existence of the IAF within the UK's distinctive regulatory approach of "comply or disclose reasons". Furthermore, it provides a theoretical framework that explains how both the agency theory and TCE theory can interpret the adoption of internal audit.

Keywords Corporate governance, Agency theory, Internal audit, Audit committee, Audit demand, Internal control and risk management

Paper type Research paper

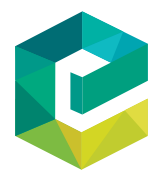

Managerial Auditing Journal Vol. 33 No. 3,2018 pp. $288-317$

Emerald Publishing Limited 0268-6902

DOI 10.1108/MAJ-08-2016-1425

\section{Introduction}

The importance of the internal audit function (IAF) as a key component of good corporate governance practice has increased as a result of repeated financial scandals and the

(C) Hazem Ramadan Ismael and Clare Roberts. Published by Emerald Publishing Limited. This article is published under the Creative Commons Attribution (CC BY 4.0) licence. Anyone may reproduce, distribute, translate and create derivative works of this article (for both commercial and noncommercial purposes), subject to full attribution to the original publication and authors. The full terms of this licence may be seen at http://creativecommons.org/licences/by/4.0/legalcode 
extensive focus by governance regulations worldwide on the concepts of internal control and risk management (Spira and Page, 2003; Gramling et al., 2004; Selim et al., 2009; Sarens, 2009). The lack of a sound internal control system is considered one of the major causes of corporate failure (Lewington, 1996), and corporate governance codes worldwide now explicitly require companies to disclose information about the effectiveness of their internal control systems (Hass et al., 2006). For instance, the UK corporate governance code requires companies to maintain a sound system of internal control and to review at least annually the effectiveness of their systems of internal controls (Financial Reporting Council, 2008). Consistent with these regulations, Sarens et al. (2009) found that IAF involvement in monitoring and improving internal controls provides a significant level of comfort to the audit committee. The IAF can provide reasonable assurance regarding the reliability of financial reporting, by detecting weaknesses in a company's financial controls (AshbaughSkaife et al., 2008; Beasley et al., 2009) and by detecting earnings management (Prawitt et al., 2009). Therefore, as one of the steps taken to improve corporate governance and investor confidence, the New York Stock Exchange (NYSE) listing rules in the USA require all listed companies to have an IAF (NYSE, 2009).

One of the key tasks of the board or its equivalent is to obtain assurance that the risk management process is working effectively and that key risks are adequately managed. The statement by the Institute of Internal Auditors (IIA) that the IAF, in both its assurance and consulting roles, contributes to the management of risk in a variety of ways is supported by various studies. For example, Sarens and De Beelde (2006) found that internal auditors in Belgium were playing a pioneering role in the creation of both greater awareness of risk and control and a more formalized risk management system. Other studies also argue that the detection of corporate fraud risk is one of the central roles that the IAF can perform (Sarens and De Beelde, 2006; Asare et al., 2008; Coram et al., 2008; The Institute of Internal Auditors, 2010b).

The IAF can contribute to corporate governance through its relationships with the audit committee, the management and the external auditor (Gramling et al., 2004). The external auditor may rely on work already performed by the IAF and/or request direct assistance from it when performing the audit. Similarly, the IAF helps both the audit committee and management in assessing risks and evaluating the effectiveness of the company's internal control system. Moreover, audit committees are increasingly relying on the IAF in discharging their responsibilities for overseeing the organization and ensuring high-quality corporate governance. This increased interaction between the audit committee and the IAF reduces the information asymmetry problem between the audit committee and executive managers (Sarens et al., 2009).

All of the discussed governance roles of the IAF are summarized in the IIA's definition of internal auditing:

Internal auditing is an independent, objective assurance and consulting activity designed to add value and improve an organization's operations. It helps an organization accomplish its objectives by bringing a systematic, disciplined approach to evaluate and improve the effectiveness of risk management, control, and governance processes. [International Professional Practices Framework (IPPF); The Institute of Internal Auditors, 2010a].

Although recent control and governance regulations, such as the US Sarbanes-Oxley Act (SOX), the UK Turnbull Guidance and Corporate Governance Code and the Committee of Sponsoring Organizations (COSO) integrated frameworks for internal controls and risk management, stressed the importance of the IAF's role, the use of an IAF is still voluntary in the UK. However, whilst the UK corporate governance code in the UK does not mandate an $\mathrm{IAF}$, companies are required to disclose, in their annual reports, whether they have one or not. In addition, if a company does not have an IAF, it must also explain the reasons for its absence, and the audit committee is required to consider annually whether there is a need for 
such a function or not (Financial Reporting Council, 2008). This UK regulatory approach of "comply or disclose reasons", while not mandating the use of an IAF, acknowledges its importance and encourages companies to have one if they need to monitor and improve the effectiveness of their internal control, risk management and governance processes. In contrast to the UK, the use of an IAF is now mandated by the NYSE listing rules in the USA (NYSE, 2009), whereas Australia or other EU countries do not require companies to have an IAF or to disclose any information about this in their annual reports (voluntary use with no disclosure) (Goodwin-Stewart and Kent, 2006a). The "voluntary use with no disclosure" approach may encourage the non-use of internal audit, even when it is necessary to the corporate governance process. In contrast, the "mandatory" approach may imply that some companies are forced to have an IAF even when it is not necessary, which may present unjustifiable extra costs, especially for relatively small companies.

While the few prior studies that investigate IAF have looked at both mandatory (USA) and voluntary compliance (Australia) countries (as discussed in Section 2), no previous research has examined the factors associated with IAF use within the UK regulatory context. Therefore, the main objective of this study is to investigate the factors that drive UK companies listed on the LSE Main Market to establish an IAF and, accordingly, to provide insights into the effectiveness of the UK regulatory approach of "comply or disclose reasons". This study contributes to the existing knowledge in many ways. First, it contributes to understanding how effective this different regulatory approach is. It is expected that a firm's characteristics (as a proxy for its need for an IAF) will affect its decision to have an IAF. Thus, the relationship between a company's decision to have an IAF and its characteristics can provide insights into the effectiveness of this regulatory approach to the governance process. Second, contrary to the previous literature discussed in Section 2, this study expects that the corporate governance structure, especially the audit committee, will affect the decision by UK listed companies to use an IAF. The governance code requires large companies to have an audit committee with at least three independent directors (smaller companies that are below the FTSE 350 need at least two), and that at least one member should have recent and relevant financial experience. In addition, the audit committee is responsible for monitoring and reviewing the financial reporting process, the internal control system and the internal and external audit work. Furthermore, the UK corporate governance context seems more likely to spread the power at the top of the firm, by enhancing the power of the board of directors to operate independently of management and effectively monitor executives' actions (Aguilera et al., 2006). There is more constraint on the exercise of CEO power in the UK than in many other countries. More than 90 per cent of UK companies split the roles of the CEO and the chairman of the board, as required by the combined code, and, therefore, no one individual should have unfettered power to make decisions. The code also requires at least 50 per cent of the board to be independent. This strong corporate governance structure in the UK may affect the board's demand for an IAF to meet its responsibilities towards shareholders and to oversee the management's actions. Thus, this research offers additional insights into the impact of a specific type of corporate governance structure on IAF use and, therefore, provides more insights into its usefulness in monitoring and improving the effectiveness of the internal control and risk management systems. Third, contrary to the prior literature, this study expects that both directors' shareholdings and major (institutional) shareholders will affect the existence of an IAF in UK listed companies. Management has become entrenched at a higher level of ownership in the UK and institutional investors are larger and more able to co-ordinate monitoring activities (Short and Keasey, 1999). As of 31 December 2003, institutional investors controlled about 80 per cent of the UK equity market (Mallin et al., 2005) and are 
increasingly able to form coalitions to monitor management's actions (Short and Keasey, 1999). Therefore, institutional investors may put more pressure on management to have more monitoring mechanisms, including an IAF. Fourth, the UK equity market is the third largest in the world and the largest in Europe, with more than 2,500 companies listed on the LSE[1] including more than 750 companies listed on its main market. Thus, the results from this study can provide regulators with a clearer picture of firms' characteristics associated with the use of IAF and therefore the results may be useful if the LSE considers mandating internal audit. Fifth, because UK companies are required to disclose in their annual reports whether they have an IAF or not, this study will have the advantage of using objective and accurate data collected from companies' annual reports, rather than relying on data collected from a questionnaire survey, as previous studies have done. Thus, the results of this study should be more robust and applicable to the population of UK non-financial companies listed on the LSE Main Market. Finally, this study provides a theoretical framework based on agency theory and transaction cost economics (TCE) theory to explain the factors affecting the adoption of an internal audit. Although these two theories are relevant to the internal audit research, prior studies have rarely used them to explain the adoption of internal audit.

Using univariate tests and multivariate logistic regression for a sample of 332 UK nonfinancial companies listed on the LSE Main Market, the study provides strong evidence that the existence of an IAF is associated with a company's size, the level of its internal risks, the external agency costs in terms of directors' shareholdings and the presence of an effective audit committee. This is consistent with agency theory, TCE theory and the IIA definition for internal auditing, suggesting that the need to have strong internal control and risk management systems to reduce both internal and external agency costs is an important driver for companies to have an IAF. In addition, these results suggest that the UK regulatory approach, which requires companies to either have an IAF or disclose the reasons for its absence, works effectively in ensuring strong monitoring mechanisms through the alignment between companies' characteristics and the existence of an IAF.

\section{Literature review}

No empirical research has investigated the factors associated with the voluntary use of internal audit by UK listed companies, although a few previous studies outside the UK have explored the factors associated with such use. Goodwin-Stewart and Kent (2006a) examined Australian publicly listed companies, using data from a survey of 450 listed companies and information from corporate annual reports. The results indicated that only one-third of the sample had an IAF. While size appeared to be the dominant driver, there was also a strong association between the use of an IAF and the existence of a risk committee, the existence of a designated risk manager and the proportion of receivables and inventories. Surprisingly, the study found only weak evidence for an association between IAF use and a strong corporate governance structure. It found only a positive and significant association with the existence of an audit committee, but it did not find any significant results for the proxies of audit committee effectiveness and the proportion of independent directors on the board. However, these findings may be affected by the fact that establishing an audit committee was voluntary for Australian listed companies when this study was conducted. Another study by Carey et al. (2000) investigated the voluntary demand for both internal and external auditing in 186 family businesses in Australia. This study used survey data to investigate the impact of four variables: firm size, debt, proportion of non-family management in the firm and proportion of non-family representation on the board of directors and showed that internal auditing was more prevalent than external auditing. It found no association between the demand for audit, either internal or external, and firm size. The other three variables were associated with the

\section{Voluntary use of internal audit}

291 
demand for external auditing but did not explain the demand for internal auditing. However, the study found a negative and significant correlation between internal and external auditing, suggesting that they are more commonly viewed as substitutes for one another rather than complementary responses in the family business environment. A third study, by Wallace and Kreutzfeldt (1991), examined the distinctive characteristics of entities with an internal audit department in a sample of 260 US companies. This study was exploratory and relied upon data collected from a questionnaire survey. The key discriminant variables were the degree of regulation, the decentralization, size, the association with present auditors, the presence of an audit committee and the EDP control and pressure from external parties on management to achieve budgetary goals.

Apart from these studies investigating the determinants of IAF use, few other studies outside the UK have investigated the factors associated with the IAF budget and the IAF size. Carcello et al. (2005) examined the factors associated with US public companies' investment in internal auditing (in terms of the IAF budget). The IAF budget is positively associated with company size, leverage, relative amount of inventory, operating cash flows and audit committee's review of the IAF's budget on the basis of publicly available data and data from a survey administered to the Chief Audit Executives of 217 midsized US public companies. In addition, some previous studies found evidence that a firm's characteristics may affect the size of its IAF. Goodwin-Stewart and Kent (2006a) found a strong positive association between IAF size and firm size and an unexpected negative association between the IAF size and the proportion of receivables, inventories and long-term debts in Australian listed companies. In addition, based on the results from a survey of 173 public and private US companies, Anderson et al. (2012) found that an organization's size, the number of subsidiaries and the audit committee characteristics were positively associated with the IAF size. Furthermore, Sarens and Abdolmohammadi (2011) found, in a sample of Belgian companies, that IAF size was positively associated with management ownership but negatively associated with the proportion of independent board members.

The results from these studies cannot be generalized to all companies and countries (especially the UK), for many reasons. First, the studies contained contradictory results. Where size appeared to be the dominant driver in some studies (Wallace and Kreutzfeldt, 1991; Goodwin-Stewart and Kent, 2006a), Carey et al. (2000) found no association between the demand for internal audit and firm size. In addition, Wallace and Kreutzfeldt (1991) found a significant relationship between the use of an IAF and decentralization (number of divisions and locations), while Goodwin-Stewart and Kent (2006a) found an insignificant relationship with the number of business segments. Furthermore, where Goodwin-Stewart and Kent (2006a) found weak support for the association between the use of internal audit and corporate governance variables, Paape et al. (2003) stated that corporate governance is an important factor in developing and positioning the IAF among the top listed companies in the European Union. Moreover, Christ et al. (2015) noted the importance of an effective audit committee in ensuring quality financial reporting. They concluded that the audit committee can be a key compensating control that provides oversight to the IAF and can strengthen its capacity and willingness to detect and prevent low-quality financial reporting. Although Goodwin-Stewart and Kent (2006a) found insignificant results for variables related to the audit committee's effectiveness, it is expected that the strong corporate governance structure in the UK, especially the audit committee, may affect the use of IAF to discharge companies' corporate governance responsibilities, as required by the governance code. Second, all previous studies relied to some extent on data collected from questionnaires and some questionnaires collected financial data using mainly categorical measures (Wallace and Kreutzfeldt, 1991; Carey et al., 2000). Accordingly, the models' 
explanatory powers were questioned and the samples used may have been biased. In contrast, the obligation to disclose the existence of an IAF in the UK allows the present study to use data collected directly from companies' annual reports for the targeted sample, rather than data from questionnaire respondents which risks being biased. Third, GoodwinStewart and Kent's (2006a) sample was weighted towards smaller listed companies; Carey et al.'s (2000) sample was weighted towards medium-sized family businesses; while Wallace and Kreutzfeldt's (1991) sample was only representative of the clients of Arthur Anderson \& Co. Fourth, both Goodwin-Stewart and Kent (2006a) and Wallace and Kreutzfeldt (1991)

Voluntary use of internal audit

293 used financial and non-financial companies in a single sample, although these two types differ in their characteristics, risks, internal control structures, motives and regulations. Fifth, all studies except Goodwin-Stewart and Kent (2006a) have ignored corporate governance variables. However, when Goodwin-Stewart and Kent (2006a) conducted their study, in contrast to the UK, there was no requirement for listed companies in Australia to have an audit committee when Goodwin-Stewart and Kent (2006a) conducted their study. In addition, Goodwin-Stewart and Kent (2006a) used "being non-executive" as a proxy for directors' independence, although it is not a sound measure of independence in the UK, where a director can be a non-executive but still considered to be not independent. Finally, the unique UK regulatory approach "comply or disclose reasons", which has not been examined by the previous research, is expected to provide robust results about the characteristics of firms that might affect the existence of an IAF. Firms' characteristics in this context, and hence their actual need for the IAF, are expected to affect their decision to use such a function or not. In contrast, and in our opinion, voluntary IAF, coupled with no requirement to disclose any information about its existence or the reasons for its absence [such as the Australian context examined by Goodwin-Stewart and Kent (2006a)], may negatively affect a company's decision to use an IAF, even where one is needed. In this case, no regulation exists to enforce management to review the company's need for an IAF.

Compared to the external auditing literature, very few researchers have applied theories to research in internal auditing. In a conceptual paper, Adams (1994) argued that agency theory can help explain the existence and responsibilities of the IAF and can provide a useful framework for conducting further empirical research. Spraakman (1997) conducted experimental research to test how TCE theory can explain both the purpose and the effectiveness of IAF as a monitoring mechanism, using an experiment to assess the usefulness of internal audit findings for senior executives in Canadian Government organizations. Sarens and Abdolmohammadi (2011) used agency theory and to investigate the association between agency variables and the relative size of the IAF in a sample of Belgian companies. However, none of the prior studies that investigated the voluntary use of internal audit made significant use of the agency theory or TCE theory to explain the factors affecting the existence of IAF in listed companies. Only Carey et al. (2000) used the agency theory, but they found no support for the four agency variables used in Australian family businesses, where the problem of separation between ownership and control is less likely to occur. In contrast, many previous studies used the agency theory to investigate firms' incentives to hire an external auditor (Chow, 1982; Tauringana and Clarke, 2000; Hay and Davis, 2004; Collis, 2010). These studies argued that the main reason for firms to hire an external auditor is to help control the conflict of interests among firms' managers, shareholders and outside creditors. Consistent with this framework, the voluntary use of an external auditor was found to be positively associated with company size and debt ratio and negatively associated with management's ownership. Furthermore, prior external auditing studies (Knechel and Willekens, 2006; Mangena and Tauringana, 2008) found some evidence for the association between the voluntary demand for external auditing and some corporate 
governance variables, especially the existence of an effective audit committee. Given the relationship between internal and external auditing, the agency theory can be also used to investigate the factors associated with the voluntary use of internal audit as a monitoring mechanism (this is discussed in more detail in Section 3).

\section{Theoretical framework and hypothesis development}

\subsection{Agency theory and the demand for internal audit}

The agency theory can help explain the presence of internal audit, the nature of the IAF and the particular approach adopted by internal auditors to their work (Adams, 1994). It postulates that a firm consists of a nexus of contracts between the owners of economic resources (the principals) and the managers (the agents) who are charged with using and controlling those resources (Jensen and Meckling, 1976; Adams, 1994). The agency theory is based upon the premise that agents have more information than principals and that this information asymmetry adversely affects the principals' ability to monitor whether their interests are being properly served by the agents. It also assumes that principals and agents act rationally and that they will use the contracting process to maximize their wealth. Jensen and Meckling (1976) stated that, if both parties to the agency relationship are utility maximizers, it is generally impossible at zero cost to ensure that the agent will make decisions that seem optimal to the principal. In most principal-agent relationships, reducing the agency problem always incurs monitoring and bonding costs.

Some writers have recognized the role of internal audit as a bonding function borne by senior managers to monitor their behaviours and to satisfy the demands for accountability made by shareholders and creditors (DeFond, 1992; Sherer and Kent, 1983). At the same time, the cost of internal audit can be also seen as a monitoring expenditure incurred by owners/principals to reduce the agency problem and protect their economic interests (Adams, 1994; Ettredge et al., 2000; Subramaniam, 2006).

In general, both internal and external auditing are hypothesized to provide monitoring intended to reduce the internal and external agency costs (Jensen and Meckling, 1976; Fama, 1980; Chow, 1982; Fama and Jensen, 1983; Francis and Wilson, 1988; Anderson et al., 1993; Adams, 1994; Ettredge et al., 2000). While internal agency costs arise due to differences in incentives between top managers and lower-level employees within the firm, external agency costs reflect differences in incentives between top managers and external suppliers of capital (Ettredge et al., 2000). On the one hand, the internal agency costs include lower-level employees' tendency to work less, immoral behaviours such as asset theft and intentional and unintentional misrepresentation of information. On the other, external agency costs may arise owing to senior managers' unfavourable incentives, such as the intentional transfer of wealth from shareholders and debt-holders to themselves, misrepresentation of information, earnings management, excessive perquisites, shirking and incorrect investment decisions.

\subsection{Transaction cost economics theory and the demand for internal audit}

TCE can explain both the purpose of an IAF and its effectiveness and efficiency as a monitoring mechanism. The purpose of internal audit under TCE is to provide information on how well the system of internal control is working and its effectiveness in monitoring and reducing risks (Spraakman, 1997). In addition, TCE argues that an internal audit provides managers with more useful information for cost economizing through its involvement in both financial and operational controls (Williamson, 1975; Williamson, 1985, cited in Spraakman, 1997). Internal audit helps identify internal control weaknesses and describes the system of internal controls. These result in information that enables managers to better understand an operation and to bring about changes for the sake of further cost 
economizing. Furthermore, internal audit can gather information not available to external auditors, who tend to be restricted to the internal controls of financial accounting (Williamson, 1975; Williamson, 1985). According to TCE theory, in companies where the activities to be controlled are acknowledged to be large and complex, the employment of an in-house IAF with industry knowledge may be a more cost-efficient contractual mechanism. Through this mechanism, principals can control shirking by agents and agents can signal to principals that they are acting responsibly, while everyone is assured that controls are in place to manage the potential financial and non-financial risks.

\subsection{Research hypotheses}

As discussed above, agency and TCE theories suggest that companies with higher levels of risk and internal and external agency costs are more likely to have an IAF to monitor management's actions, reduce information asymmetry between management and the audit committee and provide assurance about the effectiveness of the internal control and risk management systems. Based upon the assumptions of these two theories and companies' needs to monitor internal control and risk management, as required by the corporate governance regulations, the following hypotheses can explain the voluntary use of internal audit (a summary of these hypotheses is provided in Figure 1).

\subsubsection{Loss of direct control}

3.3.1.1 Firm size. The agency theory and TCE theory can be used to predict that large firms, compared with small firms, are more likely to employ internal auditors. Loss of direct control by principals is more likely to occur in large firms (Wallace and Kreutzfeldt, 1991; Carcello et al., 2005; Goodwin-Stewart and Kent, 2006a). The previous research suggested a number of theoretical explanations (Carey et al., 2000). First, with larger firms, the related benefits from

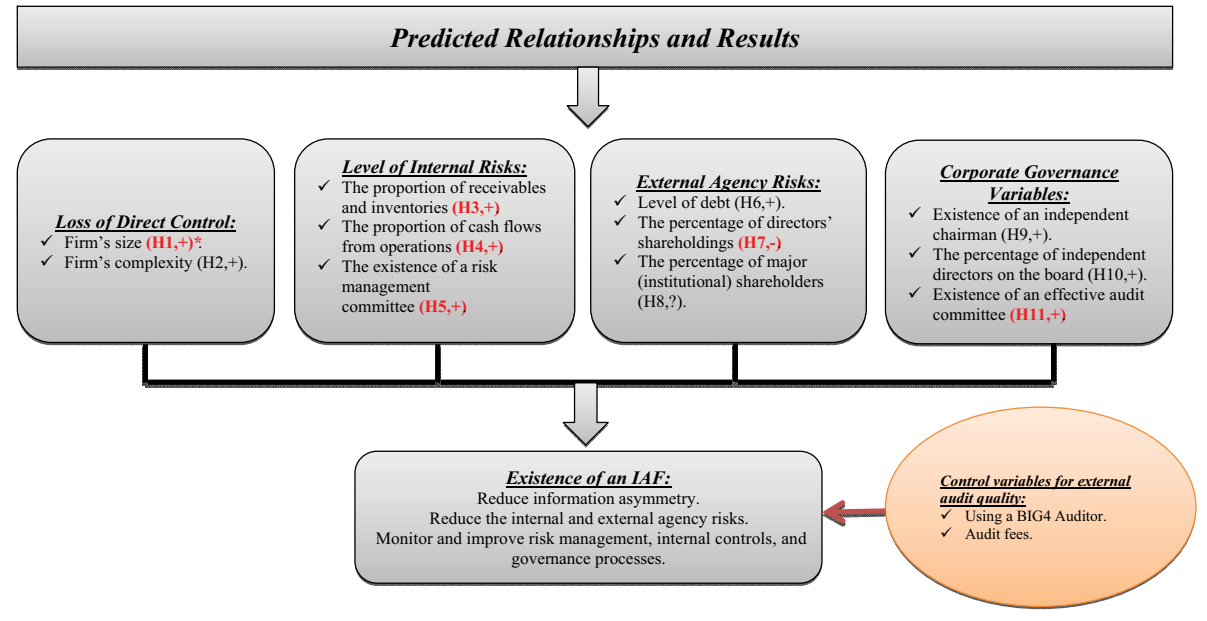

Notes: These predicted relationships and results are based upon agency theory and TCE theory and generally the IIA definition for internal auditing. The associated hypotheses and the predicted direction of the relationship are presented for each of the main explanatory variables. In addition, the figure contains the control variables that may affect the predicted relationships and results; *The hypotheses that were found significant by this study are in bold red font
Voluntary use of internal audit

295

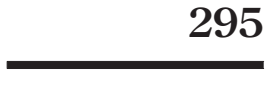


undertaking monitoring increase as a result of the increased total amount of potential wealth transfers (Chow, 1982). Second, with increased size, it becomes more difficult for the owners of a company to oversee the enterprise (Abdel-khalik, 1993). Third, because the marginal cost of providing an audit decreases with firm size (Chow, 1982), larger firms have the opportunity to take advantage of economies of scale from investing in the fixed costs of internal auditing (Anderson et al., 1993). Thus, we can formulate the first hypothesis as follows:

H1. The likelihood that a firm has an IAF is positively associated with the firm's size.

3.3.1.2 Firm complexity. Consistent with the agency theory and TCE theory, some studies have suggested that a firm's complexity, in terms of the number of segments and subsidiaries, is associated with greater decentralization, which, in turn, leads to a greater demand for monitoring (Spraakman, 1997; Carcello et al., 2005; Goodwin-Stewart and Kent, 2006a). Firms which are more complex are more likely to have information asymmetry problems, which need strong monitoring mechanisms to prevent agents' inappropriate behaviour. These firms require more decisions, more information, more transactions and more opportunities for misrepresentation and, hence, a greater need for monitoring and control. Thus, we can formulate the second hypothesis as follows:

H2. The likelihood that a firm has an IAF is positively associated with the complexity of the firm's business structure.

3.3.2 Level of internal risks. The need for monitoring is affected by the level of internal risks (Carcello et al., 2005; Goodwin-Stewart and Kent, 2006a; Knechel and Willekens, 2006). Companies with a high proportion of account receivables, inventories and cash flows from operations are more likely to have higher internal agency costs, in terms of material misstatements in their financial reports, as a result of immoral behaviour such as asset theft and the intentional and unintentional misrepresentation of information (Simunic, 1980; Francis and Stokes, 1986; Ettredge et al., 1994; Carcello et al., 2005; Goodwin-Stewart and Kent, 2006a; Knechel and Willekens, 2006). Therefore, these companies are more likely to have an IAF as a monitoring mechanism to ensure that controls are in place to manage these risks effectively. In addition, the existence of a risk management committee, established by the senior management, can indicate a high level of internal risk and, therefore, a need for effective control and risk management systems (Goodwin-Stewart and Kent, 2006a; Knechel and Willekens, 2006). Thus, we can formulate the following three hypotheses:

H3. The likelihood that a firm has an IAF is positively associated with the proportion of receivables and inventories to total assets.

H4. The likelihood that a firm has an IAF is positively associated with the proportion of operating cash flows to total assets.

H5. The likelihood that a firm has an IAF is positively associated with the existence of a risk management committee.

\subsubsection{External agency risks}

3.3.3.1 Level of debt. Agency costs are expected to be higher when the level of debt is high, because of managers' incentive to transfer wealth from creditors to shareholders (Jensen and Meckling, 1976; Chow, 1982; Bradbury, 1990; Ettredge et al., 1994; Klein, 2002; Godfrey et al., 2003). Therefore, the need for monitoring activities to mitigate this agency problem between management and the debt holders increases as the level of debt increases (Carey et al., 2000; Carcello et al., 2005). Thus, we can formulate the following hypothesis: 
H6. The likelihood that a firm has an IAF is positively associated with the level of debt in a firm's capital structure.

3.3.3.2 Directors' shareholdings. Agency costs are also expected to be higher when senior management shareholdings are proportionately low (Jensen and Meckling, 1976; Fama, 1980; Ettredge et al., 1994; Menon and Deahl Williams, 1994). A smaller managers' shareholding gives managers an incentive to allocate the firm's resources in a way that may not necessarily be consistent with the needs of non-managing shareholders (Tauringana and Clarke, 2000). In addition, Short and Keasey (1999) stated that the management could become entrenched at higher levels of ownership in the UK. Therefore, it can be predicted that, to eliminate the associated agency problem, the use of IAF by UK listed companies is negatively associated with directors' shareholdings. Thus, we can formulate the following hypothesis:

H7. The likelihood that a firm has an IAF is negatively associated with the percentage of directors' shareholdings in the firm.

3.3.3.3 Major shareholders. Agency costs are expected to be higher when there is a smaller concentration of major (institutional) shareholders (Bradbury, 1990; Collier and Gregory, 1999; Goodwin-Stewart and Kent, 2006a). Major shareholders can directly monitor the activities of management and have the power to affect managers' decisions. Bradbury (1990), for example, stated that non-executive directors can be appointed by large stockholders to exercise decision control functions on their behalf and hence there is no need for more monitoring tools. However, O'Sullivan (2000) stated that the managers of companies which are owned by large shareholders might use (or be forced to use) more monitoring mechanisms, including an IAF, to satisfy the monitoring needs of these substantial shareholders. Thus, the direction of the relationship between the percentage of major shareholders and the existence of an IAF may be positive or negative. Therefore, we can formulate the following neutral hypothesis:

H8. The likelihood that a firm has an IAF is associated with the percentage of major shareholders.

3.3.4 Corporate governance variables. Corporate governance mechanisms can include having independent directors on the board, an independent chairman, an effective audit committee and the use of both internal and external audits (Cohen et al., 2004; Davidson et al., 2005; Goodwin-Stewart and Kent, 2006a). According to the IIA definition, prior studies and agency theory, internal audit is more likely to be a complementary governance mechanism, created to reduce the information asymmetry problem between executive and independent directors. In addition, previous studies (Fama and Jensen, 1983; Ettredge et al., 1994) argued that the independent directors are more likely to use more and higher quality monitoring to oversee the management's actions and to protect their own reputation. Thus, a positive association can be predicted between the use of an IAF and both the existence of an independent board chairman and the percentage of independent directors on the board. Thus, we can formulate the following two hypotheses:

H9. The likelihood that a firm has an IAF is positively associated with the existence of an independent chairman.

H10. The likelihood that a firm has an IAF is positively associated with the percentage of independent directors on the board.

The objectives of the IAF and the audit committee are closely intertwined (Scarbrough et al., 1998). An effective IAF can enhance the effectiveness of the audit committee and vice versa
Voluntary use of internal audit 
(Braiotta, 1999; Bishop et al., 2000; Goodwin-Stewart and Kent, 2006a; Anderson et al., 2012). In particular, the audit committee is required by the UK governance code to monitor and review the integrity of the financial reporting process and the effectiveness of the internal control and risk management systems. Therefore, an effective audit committee is more likely to use an IAF when it wants to discharge its corporate governance responsibilities. Thus, we can formulate the following hypothesis:

H11. The likelihood that a firm has an IAF is positively associated with the existence of an effective audit committee.

An effective audit committee is assumed both to meet frequently and to include a majority of independent directors, as well as members with financial expertise (according to DeZoort et al., 2002; Goodwin-Stewart and Kent, 2006a; Mangena and Tauringana, 2008; Zaman et al., 2011; Anderson et al., 2012). As a result, the variables that will be used to measure the effectiveness of the audit committee are:

- audit committee size;

- percentage of independent directors;

- percentage of audit committee members with financial expertise; and

- number of audit committee meetings.

Therefore, we can formulate $H 11$ with the following four sub-hypotheses:

H11a. The likelihood that a firm has an IAF is positively associated with the audit committee size.

H11b. The likelihood that a firm has an IAF is positively associated with the percentage of independent directors on the audit committee.

H11c. The likelihood that a firm has an IAF is positively associated with the percentage of audit committee members with financial expertise.

H11d. The likelihood that a firm has an IAF is positively associated with the number of audit committee meetings.

In addition to the main explanatory variables of the study, this study uses two control variables to control for the use of a quality external auditing as a complementary or substitute monitoring mechanism. These two variables are "the use of BIG4 external auditors" and "the external audit fees as a percentage of the firm's total assets". Much of the prior literature argued that internal auditing and external auditing are characterized as monitoring mechanisms that should be partial substitutes for each other (Wallace, 1984; Anderson et al., 1993; Carey et al., 2000; Felix et al., 2001; Abbott et al., 2012). However, Ettredge et al. (2000) found no evidence of systematic substitution between internal and external audits. Furthermore, Goodwin-Stewart and Kent (2006b) found a positive association between the use of internal audit and the external audit fees, suggesting that internal and external audit may be used as complementary mechanisms to increase overall monitoring. As a result, these two control variables are used, but in a direction that cannot be identified.

\section{Research method}

\subsection{Sample and data collection}

The LSE has two markets: the Main Market and the Alternative Investment Market (AIM). The Main Market is subject to stricter regulations, especially for corporate governance, and 
represents 99 per cent of the UK's market capitalisation[2]. It includes the Financial Times Stock Exchange (FTSE) All-share and FTSE Fledgling[3]. The AIM, for its part, is a submarket of the LSE, allowing smaller companies to float shares under a more flexible regulatory system than that of the main market. Flexibility is provided by fewer regulations and no requirements for capitalisation or the number of shares issued[4].

As indicated by Table I, the sample for this study included 332 UK non-financial companies listed in the LSE Main Market in 2009. In 2009, the LSE Main Market included approximately 753 companies[5]. Financial companies were excluded from the sample because they have different regulations and specific industry control structures required by The Basel Committee on Banking Supervision and the UK Financial Service Authority. In addition, the non-financial FTSE 100 companies were excluded from the sample because they are all very large, have IAF [6] and have strong corporate governance[7]. However, the final sample indicates that the study is still focusing on the adoption of IAF by the relatively large-, mid- and small-capitalised companies listed on the LSE Main Market.

The required financial and non-financial data were collected for 2009 using Thomson Reuters DataStream[8] and companies' annual reports. Starting from 2009, companies were required to disclose in their annual reports whether they had an IAF or not and this helped the study to investigate the relationship between firm characteristics and the existence of an $\mathrm{IAF}$ in the targeted sample.

\subsection{Research model}

In addition to using univariate statistical tests, the multivariate binary logistic regression is used to identify the factors associated with the voluntary use of IAF by UK non-financial companies listed in the main market. In the logistic regression model, the dependent variable is "IAF existence", coded 1 if the company has an IAF (either in-sourced or out-sourced) and 0 if not. This model is as follows:

$$
\begin{aligned}
\text { IAF existence }= & b 0+b 1 \text { SIZE }+b 2 \text { SEGMENTS }+b 3 \text { RECINV } \\
& +b 4 \text { OCF }+b 5 \text { RISKC }+b 6 L E V-b 7 D S H+b 8 M S H \\
& +b 9 I N D C H+b 10 I N D D S+b 11 \text { ACSIZE }+b 12 \text { ACIND } \\
& +b 13 \text { ACEXP }+b 14 \text { ACMEET }+b 15 \text { BIG4 } \\
& +b 16 \text { AUDITFEES }+e
\end{aligned}
$$

Voluntary use of internal audit

299

$\begin{array}{lr}\text { FTSE All-share and FTSE Fledgling } & 753\end{array}$

Less: Financial companies $\quad-326$

\begin{tabular}{ll} 
Non-Financial FTSE All-shares and FTSE Fledgling & 427 \\
\hline
\end{tabular}

Less: Non-financial FTSE 100 companies $\quad-77$

Less: Companies with insufficient/missing data $\quad-18$

Final sample $\quad 332$

$\begin{array}{lll}\text { FTSE 250 } & 44 \% & 146\end{array}$

FTSE SmallCap $\quad 34 \% \quad 114$

$\begin{array}{lrr}\text { FTSE Fledgling } & 22 \% & 72\end{array}$

$100 \%$

Table I.

Research population and sample 
MAJ

33,3

where:

IAF existence (Dependent variable) $=1$ if the company has an IAF (either in-sourced or out-sourced, 0 if not

$=$ total assets in thousands of pounds

SIZE

SEGMENTS

RECINV

$\mathrm{OCF}$

RISKC

LEV

DSH

MSH

INDCH

INDDS

ACSIZE

ACIND

$=$ number of operating segments

$=$ receivables and inventories divided by total assets.

= operating cash flows divided by total assets

$=1$ if the company has a risk management committee, 0 otherwise

$=$ long-term debts divided by total assets.

= percentage of outstanding shares owned by directors

$=$ percentage of outstanding shares owned by the major (institutional) shareholders who own 3 per cent or more

$=1$ if the chairman is independent, 0 otherwise.

$=$ percentage of independent directors on the board

$=$ number of audit committee members

$=$ percentage of independent directors on the audit committee

ACEXP

ACMEET

BIG4 (control variable)

$=$ percentage of directors with financial expertise on the audit committee

$=$ number of audit committee meetings during the year

$=1$ when a Big Four external auditor is used and 0 otherwise

AUDITFEES (control variable) = total external audit fees divided by total assets

\section{Results}

Table II shows that 206 companies (62 per cent of the sample) have an IAF, while 126 companies (38 per cent) do not. Most telecommunications, utilities, industrials, consumer services and customer goods companies have an IAF[9]. These industries are larger than others, as shown in Table III. In addition, Table IV also shows that 84 per cent of the FTSE

\begin{tabular}{|c|c|c|c|c|c|c|}
\hline \multirow[b]{2}{*}{ Type of Industry } & \multirow[b]{2}{*}{ Count } & \multicolumn{3}{|c|}{ IAF existence } & \multicolumn{2}{|r|}{ Total } \\
\hline & & $\begin{array}{l}\text { Yes } \\
\% \text { within type } \\
\text { of industry }\end{array}$ & Count & $\begin{array}{l}\text { No } \\
\% \text { within type } \\
\text { of industry }\end{array}$ & Count & $\%$ Within sample \\
\hline Telecommunications & 4 & 80 & 1 & 20 & 5 & 1.5 \\
\hline Utilities & 3 & 75 & 1 & 25 & 4 & 1.2 \\
\hline Industrials & 86 & 74 & 31 & 26 & 117 & 35.2 \\
\hline Consumer services & 60 & 69 & 27 & 31 & 87 & 26.2 \\
\hline Customer goods & 22 & 67 & 11 & 33 & 33 & 9.9 \\
\hline Basic materials & 8 & 53 & 7 & 47 & 15 & 4.5 \\
\hline Oil and gas & 6 & 43 & 8 & 57 & 14 & 4.2 \\
\hline Technology & 13 & 42 & 18 & 58 & 31 & 9.3 \\
\hline Health care & 4 & 15 & 22 & 85 & 26 & 7.8 \\
\hline Total & 206 & 62 & 126 & 38 & 332 & 100 \\
\hline
\end{tabular}

Table II.

IAF Existence by industry type
Total 


\begin{tabular}{|c|c|c|c|c|}
\hline & & Mean $(£$ & & of interna \\
\hline Type of industry & Total assets & Net sales & Market capitalization & Or interila \\
\hline Utilities & $24,24,864$ & 785,708 & $10,21,608$ & \\
\hline Telecommunications & $19,29,716$ & $16,09,956$ & $12,80,109$ & \\
\hline Consumer services & $12,27,562$ & $11,83,341$ & 485,148 & \\
\hline Customer goods & 926,514 & 736,230 & 376,251 & \\
\hline Basic materials & 738,460 & 545,042 & 579,047 & 301 \\
\hline Industrials & 607,200 & 754,909 & 349,472 & \\
\hline Oil and gas & 559,603 & 367,948 & 533,081 & \\
\hline Technology & 320,988 & 372,022 & 289,874 & \\
\hline Health care & 171,182 & 123,230 & 141,806 & Table I \\
\hline Overall average size for the sample & 786,374 & 767,551 & 400,535 & Industry average si \\
\hline
\end{tabular}

\begin{tabular}{lrrrrrrr}
\hline \multicolumn{3}{c}{ IAF existence } & \multicolumn{3}{c}{ Total } \\
FTSE Index & Count & $(\%)$ & Count & $(\%)$ & Count & $\%$ Within the overall sample & \\
FTSE 250 & 123 & 84 & 23 & 16 & 146 & 44 & 34 \\
FTSE SmallCap & 68 & 60 & 46 & 40 & 114 & 72 & Table IV. \\
FTSE Fledgling & 15 & 21 & 57 & 79 & 72 & 100 & IAF existence by \\
Overall sample & 206 & 62 & 126 & 38 & 332 & FTSE Index \\
\hline
\end{tabular}

250 companies and 60 per cent of FTSE SmallCap companies have an IAF, while only 21 per cent of the FTSE Fledgling companies have IAF, providing preliminary evidence that the existence of an IAF is positively associated with the company's size and commitment to higher corporate governance regulations.

The univariate tests, reported in in Tables V and VI, found significant results that support the majority of the research hypotheses. There was significant association between the existence of an IAF and the company's size (Total Assets), complexity (SEGMENTS), level of internal risks (OCF and RISKC), external agency costs (LEV, DSH and MSH) and corporate governance variables (INDDS, ACSIZE, ACIND and ACMEET). These results suggest that companies which have higher internal and external agency costs and need strong internal control and risk management systems are more likely to use IAF, which is consistent with the agency and TCE assumptions. However, the univariate tests did not provide support for few hypotheses; H3 (RECINV), H9 (INDCH) and H11c (ACEXP).

As a statistical rule, the presence of a correlation coefficient above 0.8 between two or more variables in a regression model, is an indication of a serious problem of multicollinearity (Field, 2009). However, Table VII reveals that the variables used in the logistic regression are not highly correlated with each other, suggesting that multicollinearity is unlikely to be a problem in interpreting the results of the analysis. The table shows that the highest Spearman correlation coefficient between the variables is 0.625 (between SIZE and AUDITFEES). In addition, Table VIII, which presents the logistic regression model, again shows that there is no multicollinearity problem, as the largest VIF is only 2.132 (less than 10) and the smallest tolerance value is 0.469 (above 0.1).

The logistic regression model in Table VIII is statistically significant $(p<0.001)$, indicating that it is able to distinguish between companies with and without IAF. The model 
MAJ

33,3

302

Table V.

Descriptive statistics, Mann-Whitney and $t$-test (continuous variables)

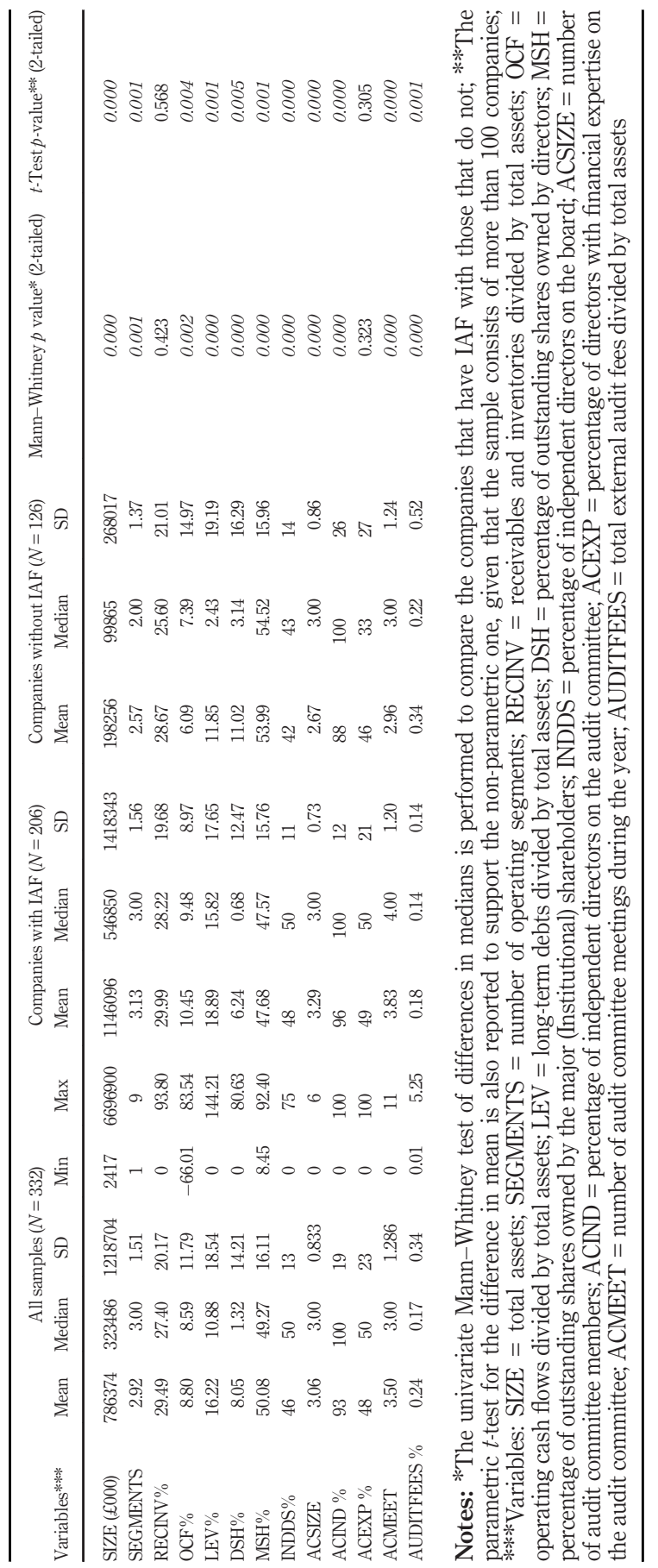


explains between 40.6 per cent (Cox and Snell $R^{2}$ ) and 55.3 per cent (Nagelkerke $R^{2}$ ) of the variance in the voluntary use of IAF and correctly classifies 80.7 per cent of the cases. Eight variables make a unique statistically significant contribution to the model at the 5 per cent level (SIZE, RECINV, OCF, RISKC, DSH, ACSIZE, ACEXP and ACMEET), while the control variable "BIG4" makes a moderate statistical contribution at the 10 per cent level. In contrast, SEGMENTS, LEV, MSH, INDCH, INDDS, ACIND and AUDITFEES are insignificant. A detailed discussion of these variables is provided below.

\subsection{Loss of direct control}

As expected, the logistic regression in Table VIII shows that the total assets (as a proxy for company size) is positive and significant at the 1 per cent level $(p<0.001)$, providing strong evidence that large firms are more likely to have an IAF than small firms. This is consistent with $H 1$ and with the idea that the loss of direct control is more likely to occur in large firms (Goodwin-Stewart and Kent, 2006a; Carcello et al., 2005; Wallace and Kreutzfeldt, 1991) where it becomes more difficult to oversee the enterprise directly. It is also consistent with prior internal auditing research (Goodwin-Stewart and Kent, 2006a; Carcello et al., 2005) and prior research about the demand for external auditing (Collis, 2010; Mangena and Tauringana, 2008; Knechel and Willekens, 2006; Hay and Davis, 2004; Tauringana and Clarke, 2000; Anderson et al., 1993). However, this differs from the situation in family businesses, where the agency problem is low; Carey et al. (2000) found no association between size and the demand for internal audit in family businesses in Australia.

The number of operating segments as a proxy for the firm's complexity is positive (as expected) but insignificant ( $p=0.783$ ), suggesting no evidence pertinent to $H 2$. This result matches what previous internal auditing research has found (Goodwin-Stewart and Kent, 2006a; Carcello et al., 2005). Therefore, as a sensitivity analysis, the number of operating segments was replaced by the number of subsidiaries. However, the results are substantially the same and the same eight variables still make a unique statistically significant contribution to the model at the 5 per cent level, while the number of subsidiaries is also insignificant. The Pseudo $R^{2}$ and the model chi-square are virtually identical and the classification rate is still 81 per cent.

\subsection{Level of internal risks}

As predicted, Table VIII shows that the proxies for the level of internal risks, namely, RECINV, OCF and RISKC, are all positive and significant $(p=0.017, p=0.042$ and $p=$ 0.001 respectively), providing evidence for $H 3, H 4$ and $H 5$, respectively. These results

\begin{tabular}{|c|c|c|c|c|}
\hline Variables** & $\begin{array}{c}\text { All samples } \\
(N=332) \\
\text { Proportion } \\
\%\end{array}$ & $\begin{array}{l}\text { Companies with } \\
\text { IAF }(N=206) \\
\text { Proportion \% }\end{array}$ & $\begin{array}{l}\text { Companies without } \\
\text { IAF }(N=126) \\
\text { Proportion \% }\end{array}$ & $\begin{array}{l}\text { Chi-square } p \text { value* } \\
\text { (two-tailed) }\end{array}$ \\
\hline RISKC & 21 & 31 & 5 & 0.000 \\
\hline INDCH & 47 & 48 & 47 & 0.910 \\
\hline BIG4 & 89 & 97 & 76 & 0.000 \\
\hline
\end{tabular}

Notes: ${ }^{*}$ The chi-square test of independence is used to compare the proportions of the dichotomous variables; ${ }^{* *}$ Variables: INDCH $=1$ if the chairman is independent, 0 otherwise; RISKC $=1$ if the company has a risk management committee, 0 otherwise; BIG4 $=1$ when a Big 4 external auditor is used and 0 otherwise
Voluntary use of internal audit

303

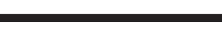




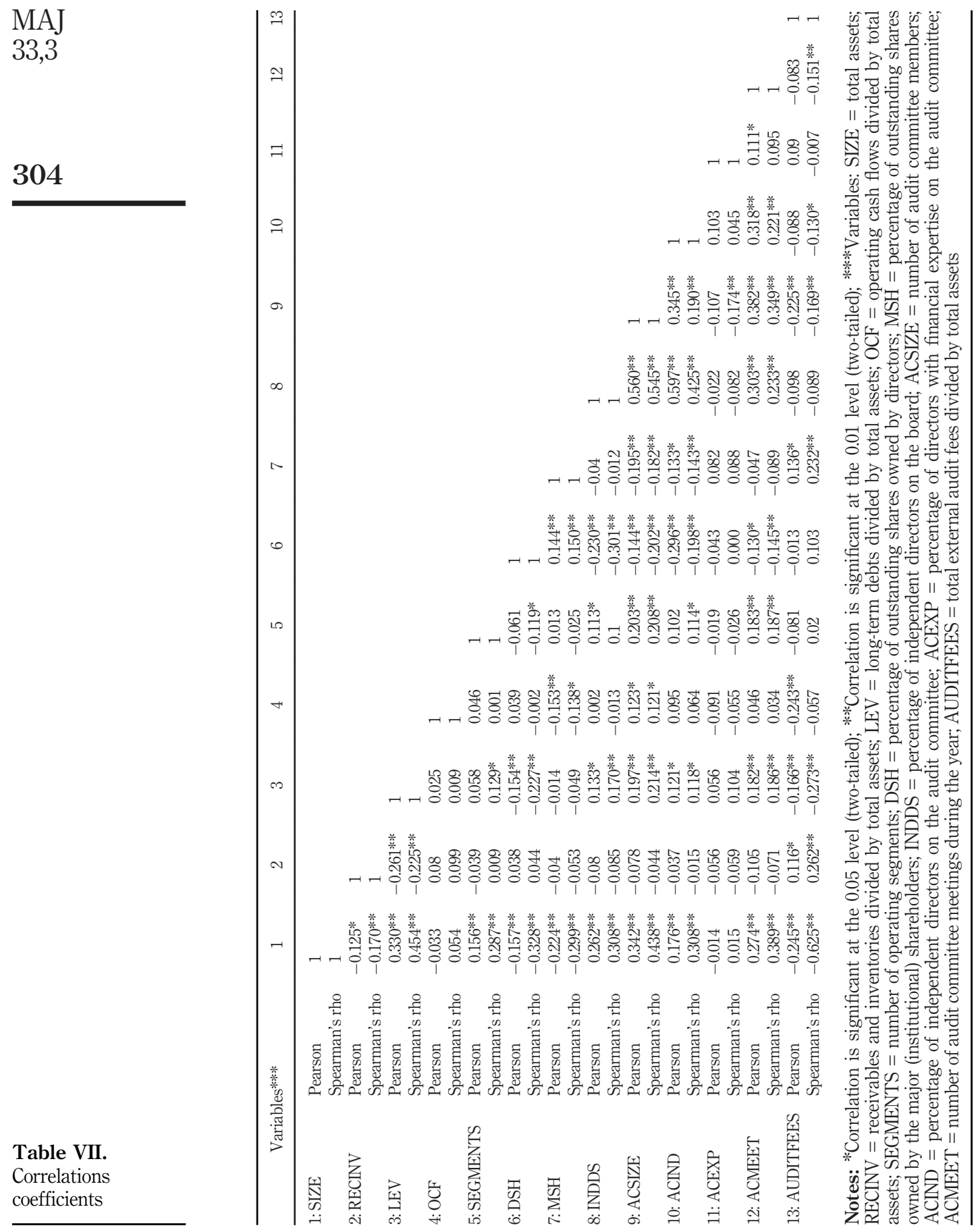




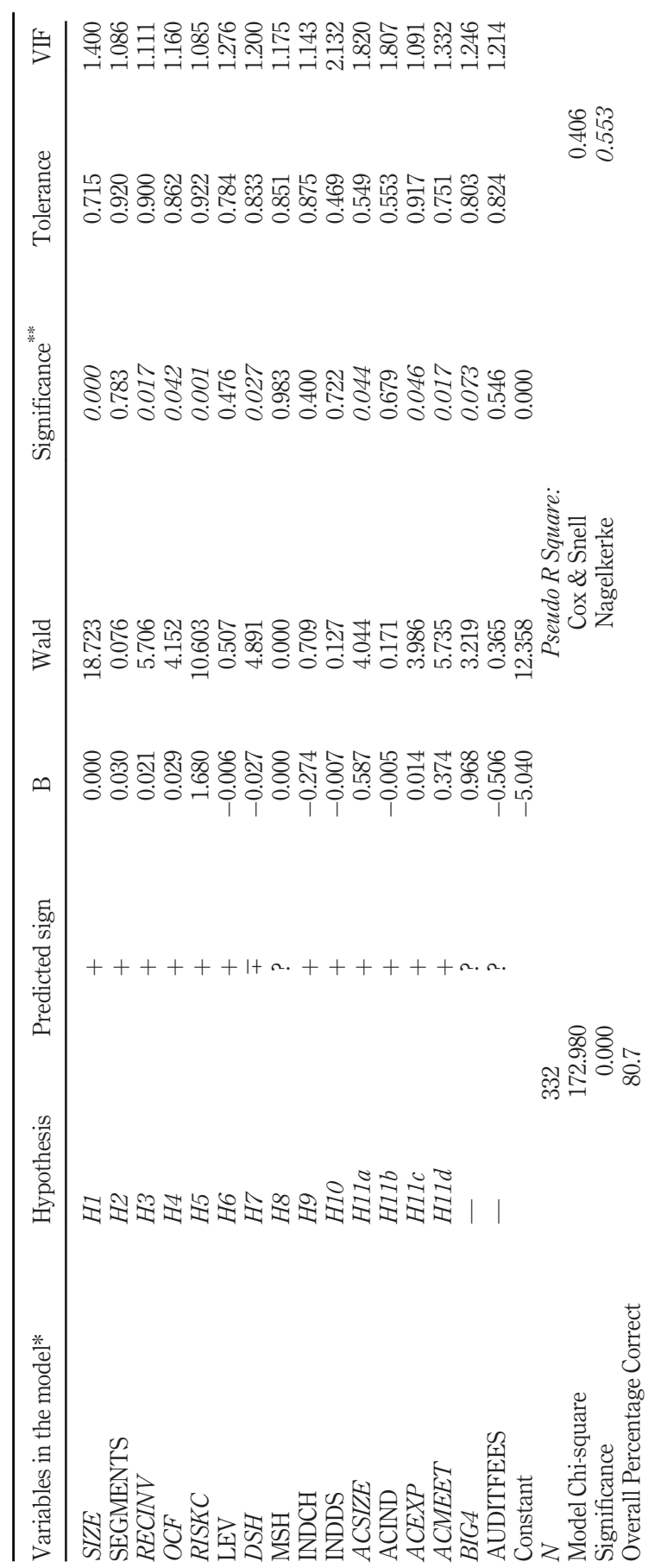

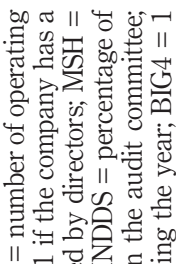

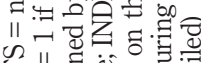

ص॥

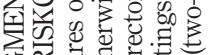

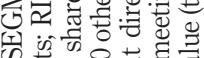
sis 证。

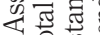

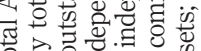

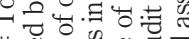
II 80.00000

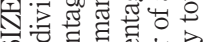
n

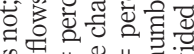
कै 11 \& 11 :

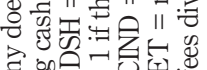

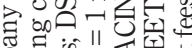

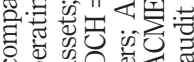

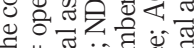

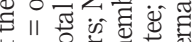

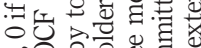

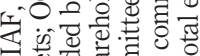

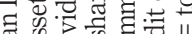
o

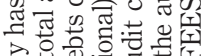

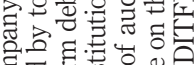

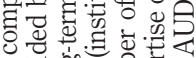
:

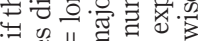

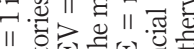

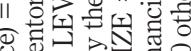

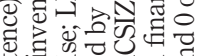

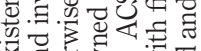

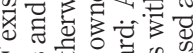

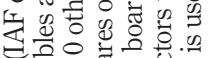

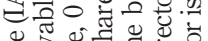

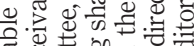

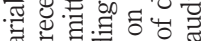
$>\| 1$ ह 윰

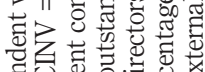

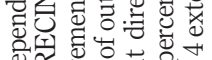

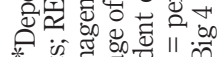

Table VIII. iि 记 model 
may suggest that companies with higher levels of internal risks are more likely to have an IAF to monitor financial and non-financial risks, consistent with the assumptions of both the agency and TCE theories. These significant results for RECINV and OCF are consistent with prior internal and external research (Goodwin-Stewart and Kent, 2006a; Knechel and Willekens, 2006; Carcello et al., 2005; Francis and Stokes, 1986; Simunic, 1980). Companies with high levels of receivables, inventories and operating cash flows are more likely to have material misstatements in their financial reports and hence more likely to demand monitoring in terms of both external and internal audits. In addition, the positive and significant result for RISKC is consistent with Goodwin-Stewart and Kent's (2006a) result, providing evidence about the importance of an IAF as a key component of an integrated risk framework that deals with both financial and nonfinancial risks.

\subsection{External agency risks}

Contrary to the expectations of this study, Table VIII shows that leverage (LEV), as a proxy for the agency problem between debt providers and owners/managers, is negative (not as expected) and insignificant ( $p=0.476$ ), providing no support for $H 6$ and suggesting no association between the existence of an IAF and the level of debt. However, this insignificant result is consistent with Goodwin-Stewart and Kent's (2006a) result, although the previous external auditing literature (Chow, 1982; Carey et al., 2000; Tauringana and Clarke, 2000; Hay and Davis, 2004) found a positive and significant relationship between leverage and the voluntary demand for external audit. These different results reveal that leverage can explain the demand for external audit but it cannot explain the demand for internal audit, suggesting that debt-holders rely for their funding decisions on audited annual reports and the opinions of external auditors.

Consistent with the expectation of this study, Table VIII shows that DSH as a proxy for the agency problem between owners and managers is negative and significant $(p=0.027)$, providing statistical support for $H 7$ and suggesting that companies with a lower percentage of outstanding shares owned by directors (higher agency problem) are more likely to have an IAF as a monitoring mechanism. This is consistent with Tauringana and Clarke (2000), who found a negative and significant relationship between directors' shareholdings and the voluntary demand for external audit, suggesting that both internal and external auditing are used to reduce the agency costs between owners and managers. However, this result contrasts with that of Goodwin-Stewart and Kent (2006a), who found a negative but insignificant result for directors' shareholdings. While this study used the actual percentage of directors' shareholding as reported in the UK companies' annual reports, GoodwinStewart and Kent (2006a) used a dummy variable equalling 1 when directors' shareholdings were greater than 5 per cent and 0 otherwise. Therefore, as a sensitivity analysis, the actual percentage of directors' shareholdings was replaced by a dummy variable DSH2 (equals 1 when directors' shareholdings are greater than 5 per cent and 0 otherwise). However, the results are substantially the same. The Pseudo $R^{2}$ and the model chi-square are virtually identical and the classification rate is 81.6 per cent. In addition, the dummy variable DSH2 is again negative and significant and the same seven other variables still make a unique statistically significant contribution to the model at the 5 per cent level.

Table VIII, in contrast, shows that MSH is positive and insignificant ( $p=0.983)$, providing no support for $H 8$ and suggesting no association between the existence of an IAF and the percentage of outstanding shares owned by major shareholders, consistent with Goodwin-Stewart and Kent's (2006a) results. 


\subsection{Corporate governance variables}

Table VIII shows that the variables related to the independence of directors (INDCH, INDDS, ACIND) are negative and insignificant $(p=0.400, p=0.722$ and $p=0.679$, respectively), providing no support for $\mathrm{H} 9$ and $\mathrm{H} 10$ and suggesting no relationship between the existence of an IAF and the independent directors on the board. In contrast, ACSIZE, ACEXP and ACMEET are positive and significant $(p=0.044, p=0.046$ and $p=0.017$, respectively), providing evidence supporting $H 11 a, H 11 c$ and $H 11 d$, respectively, and suggesting that the existence of an IAF is positively associated with the presence of an effective audit

committee. This is consistent with the UK regulatory system, which requires the audit committee to monitor and evaluate the effectiveness of risk management, internal controls and financial reporting and to evaluate annually the need for an IAF to help meet these governance responsibilities. However, this result differs from the study of Goodwin-Stewart and Kent (2006a) which found insignificant results for the audit committee's effectiveness. This difference may be due to the different governance context tested by this study, whereas the establishment of the audit committee by the Australian listed companies was voluntary, with no requirements for its structure or responsibility.

The logistic regression in Table VIII shows the individual impact of each of the audit committee's effectiveness variables. As a robustness test, the logistic regression was repeated after using an aggregate score from a seven value scale for the audit committee's effectiveness (similar to that in Knechel and Willekens, 2006) instead of testing them individually. This aggregate score consisted of AC existence ( 1 if the company has an audit committee, 0 otherwise), AC SIZE $>=$ median ( 1 if the audit committee size is 3 or more, 0 otherwise), 100 per cent $\mathrm{AC}$ independence (1 if all members are independent, 0 otherwise), number of AC members with financial expertise ( 0 to 3 ) and number of $\mathrm{AC}$ meetings $>=$ median ( 1 if the audit committee met 3 times or more, 0 otherwise). This new model is statistically significant and correctly classifies 81 per cent of cases. The AC effectiveness score is positive and significant at the 1 per cent level $(p=0.001)$, consistent with the results provided in Table VIII. In addition, the same variables still make a statistically significant contribution to the model at the 5 per cent level (SIZE, RECINV, OCF, RISKC, DSH), while BIG4 still makes a moderate statistical contribution at the 10 per cent level.

\subsection{External auditing variables (the control variables)}

Table VIII shows that BIG4 is significant at the 10 per cent level $(p=0.073)$, providing moderate evidence for the relationship between the existence of an IAF and the use of a Big4 audit firm. In addition, and similar to Goodwin-Stewart and Kent's (2006a) results, Table VIII shows that the percentage of AUDITFEES is insignificant $(p=0.546)$, providing no evidence for the relationship between the existence of an IAF and the proportion of the external auditing fees.

\section{Principal components analysis for governance variables}

As a further robustness test to capture the variability in the corporate governance variables, further variables such as board size (BOARDSIZE), percentage of non-executive directors (NEDs) and separation between chairman and CEO responsibilities (NODUALITY) were introduced to the model and a principal component analysis (PCA) for the continuous governance variables was carried out. The PCA is able to produce factors from the original variables in a way that captures most of their variability (Pallant, 2007).

The PCA reveals the presence of two components with eigenvalues exceeding 1 , explaining a total of 60.8 per cent of the variance. Three variables related to independence (INDDs, NEDs and ACIND) had strong loading (above 0.4) with the first component. As a result, the first component can be renamed the "independency 
MAJ

33,3

\section{8}

Table IX.

The logistic regression model using CG factors component" and denoted in the regression model as CGFAC1. Four variables (BOARDSIZE, ACEXP, ACSIZE and ACMEET) had strong loading with the second component. Given that three of these factors are related to the presence of an effective audit committee, the second component can be thought of as "audit committee effectiveness" and denoted in the regression model as CGFAC2.

The regression scores for the previous two components were used in a logistic regression model, as shown in Table IX. Table IX shows that INDCH, NODUALITY and CGFAC1 (the independency component) were insignificant ( $p=0.301,0.217$ and 0.442 , respectively) while CGFAC2 (the audit committee effectiveness component) was highly significant at the 1 per cent level $(p=0.001)$. These results are consistent with the results reported before in Table VIII and provide strong evidence that the existence of an IAF is positively associated with the existence of an effective audit committee.

\section{Additional analyses}

\subsection{Profitability and liquidity}

Although no previous study has investigated the effect of profitability and liquidity on the existence of an IAF, the effect of these two variables was tested to reflect the company's ability to pay for this monitoring function. However, after introducing proxies for liquidity (the Quick Ratio) and profitability (ROA) to the main model, the results remained the same, as both ROA and the Quick Ratio were insignificant, suggesting no association between profitability and liquidity and the existence of an IAF.

\subsection{Service sectors}

The descriptive statistics in Table II indicated that most telecommunications, utilities and consumer service firms have an IAF; this is consistent with Carcello et al. (2005), who

\begin{tabular}{|c|c|c|c|c|c|}
\hline Variables in the equation* & $\mathrm{B}$ & Wald & Significance ${ }^{* *}$ & Tolerance & VIF \\
\hline SIZE & 0.000 & 16.875 & 0.000 & 0.700 & 1.429 \\
\hline SEGMENTS & 0.016 & 0.021 & 0.884 & 0.916 & 1.092 \\
\hline RECINV & 0.021 & 5.793 & 0.016 & 0.901 & 1.110 \\
\hline$O C F$ & 0.028 & 4.418 & 0.036 & 0.879 & 1.137 \\
\hline RISKC & 1.615 & 9.810 & 0.002 & 0.923 & 1.083 \\
\hline LEV & -0.005 & 0.280 & 0.597 & 0.784 & 1.276 \\
\hline DSH & -0.027 & 4.998 & 0.025 & 0.816 & 1.225 \\
\hline MSH & 0.001 & 0.015 & 0.903 & 0.882 & 1.133 \\
\hline INDCH & -0.338 & 1.071 & 0.301 & 0.856 & 1.168 \\
\hline NODUALITY & 0.881 & 1.522 & 0.217 & 0.837 & 1.195 \\
\hline CGFAC1 & 0.152 & 0.591 & 0.442 & 0.708 & 1.413 \\
\hline$C G F A C 2$ & 0.701 & 11.997 & 0.001 & 0.686 & 1.457 \\
\hline BIG4 & 0.811 & 2.353 & 0.125 & 0.804 & 1.244 \\
\hline AUDITFEES & -0.313 & 0.154 & 0.695 & 0.825 & 1.212 \\
\hline Constant & -2.680 & 6.147 & 0.013 & & \\
\hline $\mathrm{N}$ & 332 & \multicolumn{4}{|c|}{ Pseudo R Square: } \\
\hline Model chi-square & 171.027 & & \multicolumn{2}{|c|}{ Cox \& Snell } & 0.403 \\
\hline Significance & 0.000 & & \multirow{2}{*}{\multicolumn{2}{|c|}{ Nagelkerke }} & 0.548 \\
\hline Overall $\%$ correct & 79.8 & & & & \\
\hline
\end{tabular}

Notes: ${ }^{*}$ New variables: NODUALITY $=1$ if the chairman is not also the CEO, 0 otherwise; CGFAC1 = the regression scores for the first component (independency) derived by PCA; CGFAC2 = the regression scores for the second component (audit committee effectiveness) derived by PCA. ** $p$-Value (two-tailed) 
suggested that service and utilities companies are more likely to invest in IAF than others. Therefore, the effect of being a service or utility company on the results reported above was tested by introducing a dummy variable for service industries (telecommunications, utilities and consumer services) to the logistic regression analysis[10]. The new results were substantially similar to these reported in Table VIII. The same variables still make a unique statistically significant contribution to the model at the 5 per cent level, and an insignificant result was found for the dummy variable for service industries, suggesting that the results were not affected by being a service company.

Voluntary use
of internal
audit

309

\section{Discussion and conclusion}

This study provides strong evidence that a firm's characteristics, namely, size, level of internal risks, agency problem between owners and managers and existence of an effective audit committee, are associated with the existence of an IAF in the UK companies listed on the LSE Main Market. It found a strong positive and significant association between firm size and the existence of an IAF. Large companies are more likely to demand monitoring to compensate for the loss of direct control and for the information asymmetry problem between the owners/board and the executive managers.

The study also found a positive and significant association between the existence of an IAF and all the proxies related to the level of internal risks (RECINV, OCF and RISKC). Companies with higher levels of internal risks are more likely to have material misstatements in their financial reports and are therefore more likely to use an IAF to insure that internal controls are in place to monitor financial and non-financial risks. In addition, the significant association between the existence of a risk management committee and the existence of an IAF may provide evidence that the need to have a strong risk management system is one of the key factors that lead companies to have an IAF, endorsing the importance of the IAF's role in monitoring and improving the systems of internal control and risk management.

As expected, the study found a negative and significant statistical result for directors' shareholdings, suggesting that the existence of an IAF is associated with the agency problem between owners and managers. The board's need to reduce the information asymmetry problem and to observe management's actions is considered one of the key factors that lead UK companies listed in the main market to have an IAF. This new result in the UK (compared to Goodwin-Stewart and Kent (2006a), who found an insignificant result for directors' shareholdings in Australia) is consistent with the agency theory and can be explained by the distinctive UK system. While management can become entrenched at higher levels of ownership in the UK, the corporate governance context seems to enhance the power of the board of directors and requires the existence of an effective audit committee. In addition, the audit committee is required by the UK code to monitor the integrity of financial reporting and to consider annually the need for an IAF as a monitoring mechanism. This regulatory system might encourage the board to establish an IAF as a monitoring mechanism to reduce agency costs, suggesting the effectiveness of the UK regulatory system in monitoring these costs.

The study also found a significant positive association between the presence of an effective audit committee and the existence of an IAF. This new result, in the UK context, reveals that an effective audit committee uses an IAF as a complementary governance tool to increase the overall monitoring of an organisation's activities. Internal audit helps the audit committee meet its responsibilities for overseeing the systems of internal control and risk management, as required by the UK corporate governance code, and to reduce the information asymmetry problem with the executive managers. This result underlines the 
importance of the relationship between the audit committee and the IAF and of having an effective audit committee (as required by the UK code) to ensure the presence of sufficient monitoring mechanisms (including internal audit) within the company.

To conclude, the study provides strong evidence that the agency theory and the TCE theory can explain the voluntary use of IAF by UK listed companies. The need to have strong internal control and risk management systems to reduce both internal and external agency costs and to improve the corporate governance process is an important driver for the existence of an IAF in these companies, supporting the usefulness of having IAF. These results are also consistent with what UK companies with no IAF disclose in their annual reports. The most common reason disclosed for the absence of an IAF is that it is inappropriate, given the size and complexity of the firm (such as Clarkson PLC, Consort Medical PLC and Oxford BioMedica PLC). Others also stated that the current control mechanisms are sufficient and no material benefit would be derived from instituting an IAF (such as Centaur Media PLC, Clarke (T) PLC, Hardy Oil \& Gas PLC, Headlam Group PLC). These reasons, given by UK companies in their annual reports, complement the results obtained by the study and suggest that:

- firms' characteristics affect their decision to use an IAF;

- use of an IAF in the UK is associated with factors related to the costs and benefits; and

- existence of an IAF is an important way of increasing the overall monitoring of a firm's control systems.

This study contributes to the existing literature in many ways. First, no other study has yet examined the factors associated with the voluntary use of internal audit in the UK regulatory system. This system has produced some new insights and brought up evidence suggesting that internal audit is useful for companies and that the UK governance regulations are effective in reducing internal and external agency costs and in monitoring the effectiveness of the internal control system. The UK corporate governance system:

- gives more power to the board of directors, with a requirement to monitor the company's internal controls effectively;

- requires companies to have an effective audit committee, which is considered crucial to the overall monitoring process, including the establishment of an IAF;

- requires companies to consider the benefits of having an IAF; and

- requires companies to provide reasons for not having an IAF.

All these things will encourage companies that need an IAF (based upon their characteristics) to have one. Second, the UK regulatory approach that requires companies to disclose whether they have an IAF or not gave the present study the chance to use accurate and objective data collected from the companies' annual reports, instead of relying on data collected from questionnaires, as previous studies had done. In addition, this approach enabled the study to use the whole population of the UK non-financial companies listed on the LSE Main Market (except for the FTSE 100), rather than using a sample biased by companies' responses to the questionnaire. Third, this study provides strong evidence that audit committee effectiveness is an important factor that affects the existence of an IAF, and this contributes to our understanding of the importance of this relationship in meeting the corporate governance responsibilities as required by the combined code. Fourth, this study tested more corporate governance variables, used 
appropriate proxies to measure these variables and used the PCA to group them together into factors that accurately capture the variation in corporate governance practices and yield robust results. In addition, the effect of profitability and liquidity was tested, and the results provide evidence supporting the idea that the agency and TCE variables explain the use of IAF, and not the ability to pay for this function. Finally, this empirical study applied both agency and TCE theories to explain the economic factors affecting IAF use within the UK regulatory context.

The results of this study have important implications for both practice and academia.

Voluntary use of internal audit From a practice standpoint, the study highlights the important role of IAF in reducing internal and external agency problems and generally in monitoring and improving internal control, risk management and governance processes. Therefore, the control and governance regulations in other countries, such as Australia, where IAF use is voluntary and no disclosure of its existence or practices is required, should:

- focus more on stressing the need for an IAF to monitor the internal control and risk management systems;

- require companies to evaluate the need to maintain an IAF, based upon their characteristics; and

- effectively articulate the position of the IAF within the firm's governance process, especially its relationship with the audit committee, as this relates directly to the process of monitoring the firm and the effectiveness of corporate financial reporting.

In addition, it may be useful if the governance regulations that mandate IAF use (including the UK regulations) admit the possibility of mandating the establishment of an IAF in all large and very large companies. Although the existence of an IAF may not be appropriate for some small companies (where the costs can exceed the benefits), an IAF seems to add significant value to large companies, in terms of ensuring the effectiveness of their risk management, internal control and governance processes. Moreover, it might be better if the regulations that mandate IAF use (such as the NYSE listing rules in the USA) required companies also to disclose some relevant information regarding the role of the IAF and its added value to the stakeholders. This can help evaluate the rationality of mandating IAF adoption in all companies, regardless of their characteristics. Furthermore, given its importance as an internal governance tool, it might be useful for investors and other users if regulations required companies to disclose in their annual reports some information about their IAF's profile and practices, as well as its role in monitoring and improving internal control, risk management and governance processes. The study also highlights the usefulness of having an effective audit committee for the overall monitoring process, including the use of internal audit as an internal governance tool. The study found a significant positive relationship between the existence of an IAF and the existence of an effective audit committee. This result complements those obtained by some earlier studies (Carcello et al., 2005; Anderson et al., 2012) regarding the positive impact of the audit committee characteristics upon the IAF's size and budget. Accordingly, the governance regulations worldwide should ensure that companies maintain effective audit committees. In addition, consistent with the IIA standards, the governance regulations should provide the board and the audit committee with more responsibility for the IAF's adoption, resources, budget and independence.

From the academic perspective, the study suggests several avenues for future research. First, the study provided evidence that factors related to control, risk, agency and corporate governance are associated with a company decision to have an IAF voluntarily. However, 
future research should investigate (using in-depth methods such as surveys or interviews) whether this function actually adds value to companies, in terms of having a positive impact on internal control, risk management and governance processes. The existence of an IAF does not always mean that it is effective and adds value to the company. In practice, there might be a separation (intentional or unintentional) between the actual organisational structures and procedures and their external expectations or imagery, which has been referred to as "decoupling" (Meyer and Rowan, 1977; Moll et al., 2006). According to the IIA standards, an effective IAF should have certain quality characteristics, provide a wide range of assurance and consulting activities to companies and have a positive impact on monitoring and improving internal control, risk management and governance processes. Second, this study complements the current picture of factors associated with IAF adoption, size and budget. However, future research that investigates the relationship between firm's characteristics (including the corporate governance structure) and IAF characteristics (such as independence and objectivity, methodology and competence) will be useful to complete the picture. Third, the predicted relationships and results (Figure 1) used in this study are investigated in a unique regulatory setting that has not been examined before. This UK setting provided a logical justification for the new significant results for some variables (such as directors' shareholding and the audit committee's effectiveness). Therefore, investigating these relationships and results in other settings may enrich existing knowledge about the factors affecting IAF use, especially the factors related to corporate governance structure and ownership structure. Fourth, contrary to the external auditing literature, the study found no association between IAF presence and the level of debt. Therefore, future research should investigate in depth why leverage explains the demand for external audit but not for internal audit. Future research should answer questions such as: Is the level of debt considered a proxy for the ability to pay for an IAF, rather than a proxy for the external agency costs within the internal auditing context? Are the debt-holders less likely to rely on the IAF report and instead rely on the audited annual reports and the opinion of external auditors in making their funding decisions? Does the current level of limited disclosure about the IAF and its role affect the debt-holders' awareness of the usefulness of having an IAF? Finally, future research should investigate the usefulness of disclosing extra information about the IAF profile, practices and roles and the impact this has on investors.

This study is subject to some limitations that may limit its generalizability. The scope of the study's results is limited to non-financial companies listed on the LSE Main Market. In financial organisations, external institutional pressures (special regulations and control structures) significantly affect the IAF adoption, characteristics and practices. Thus, future research based upon case studies in a highly regulated industry such as banks where IAF is mandatory would complement existing large sample studies and provide greater insight into IAF practices and its corporate governance role. In addition, because the non-financial FTSE 100 companies were excluded, the results may not be generalizable to the population of all non-financial companies listed on the LSE Main Market. The results of this study represent large, medium and small companies (FTSE 250, FTSE SmallCap and FTSE Fledgling), which may not be generalizable to very large companies (FTSE 100). However, FTSE 100 companies were excluded because they would bias the results regarding the factors that affect the use of an IAF towards large companies and therefore distort the findings. In addition, the study collected data for 2009 annual reports and this may limit its generalizability from one year to another. However, we do not expect a big change in the results even when the year is different. This is because the use of an IAF is still voluntary in the UK and it is unlikely that companies will establish this costly function if they have no economic reason to do so. Finally, this study investigated the association between the 
hypothesized variables and the existence of an IAF. However, this does not imply a relationship of causality between these variables and the IAF existence.
Voluntary use of internal audit

\section{Notes}

1. See www.world-exchanges.org

2. See www.ftse.com/products/indices/uk

3. FTSE All-Share Index is the aggregation of the FTSE 100, FTSE 250 and FTSE SmallCap indices and representing 98\%-99\% of the UK market capitalisation. The FTSE Fledgling Index comprises companies that are listed on the LSE Main Market, but are too small to be included in the FTSE All-Share.

4. See www.londonstockexchange.com/home/homepage.htm

5. London Stock Exchange website, Morningstar website and FTSE Russell website were used to identify the research sample.

6. As an exploratory step in this study, the annual reports of the UK companies listed on the LSE were reviewed by the authors to check which companies had an IAF and which had not. This process revealed that all the non-financial FTSE 100 had an IAF.

7. FTSE 100 companies are the largest listed companies on the LSE Main Market, and they were expected to have strong corporate governance structure. Therefore, as an exploratory (pilot) step of this study, the corporate governance variables were collected from the annual reports of a small sample of the FTSE 100 (i.e. 20 non-financial companies). The data indicated that these companies have better corporate governance structures and almost always follow the UK governance code. This small sample had, on average, 11 members on the board with more than $60 \%$ non-executive and more than $55 \%$ independent directors. In addition, the audit committees in this small sample had on average of four members, $100 \%$ independent directors and more than one person with financial experience (the average was $45 \%$ with financial expertise, and some companies had three members with financial expertise on the audit committee). Furthermore, the audit committees in this small sample met five times per year, on average.

8. Thomson Reuters Datastream is a powerful financial database that allows users to generate financial data, identify and examine trends, generate and test ideas and develop viewpoints on the market. For more details see: http://financial.thomsonreuters.com/en.html

9. Industries were classified according to the Industry Classification Benchmark (ICB) used by FTSE UK Index Series.

10. No dummy variables were used for the other industries because:

a -No theoretical basis or industry requirement states that any of the other non-financial industries need special control structures as the case in the financial sector for example.

$\mathrm{b}$-Doing this will provide inaccurate results because the logistic regression analysis needs sufficient number of cases in each category which many industries such as telecommunications, utilities, basic materials, oil and gas, technology and health care cannot provide (Table II).

\section{References}

Abbott, L.J., Parker, S. and Peters, G.F. (2012), "Audit fee reductions from internal audit-provided assistance: the incremental impact of internal audit characteristics", Contemporary Accounting Research, Vol. 29 No. 1, pp. 94-118.

Abdel-khalik, A.R. (1993), "Why do private companies demand on audit? A case for organizational loss of control”, Journal of Accounting, Auditing and Finance, Vol. 8 No. 1, pp. 31-52. 
MAJ

33,3

Adams, M.B. (1994), “Agency theory and the internal audit”, Managerial Auditing Journal, Vol. 9 No. 8, pp. 8-12.

Aguilera, R.V., Williams, C.A., Conley, J.M. and Rupp, D.E. (2006), "Corporate governance and social responsibility: a comparative analysis of the UK and the US", Corporate Governance: An International Review, Vol. 14 No. 3, pp. 147-158.

Anderson, D., Francis, J.R. and Stokes, D.J. (1993), "Auditing, directorships and the demand for monitoring”, Journal of Accounting and Public Policy, Vol. 12 No. 4, pp. 353-375.

Anderson, U.L., Christ, M.H., Johnstone, K.M. and Rittenberg, L.E. (2012), “A post-SOX examination of factors associated with the size of internal audit functions", Accounting Horizons, Vol. 26 No. 2 , pp. 167-191.

Asare, S.K., Davidson, R.A. and Gramling, A.A. (2008), "Internal auditors' evaluation of fraud factors in planning an audit: the importance of audit committee quality and management incentives", International Journal of Auditing, Vol. 12 No. 3, pp. 181-203.

Ashbaugh-Skaife, H., Collins, D., Kinney, W.R. Jr and LaFond, R. (2008), "The effect of SOX internal control deficiencies and their remediation on accrual quality", The Accounting Review, Vol. 83 No. 1, p. 217.

Beasley, M.S., Carcello, J.V., Hermanson, D.R. and Neal, T.L. (2009), "The audit committee oversight process", Contemporary Accounting Research, Vol. 26 No. 1, pp. 65-122.

Bishop, W.G., III, Hermanson, D.R., Lapides, P.D. and Rittenberg, L.E. (2000), “The year of the audit committee", The Internal Auditor, Vol. 57 No. 2, p. 46.

Bradbury, M.E. (1990), "The incentives for voluntary audit committee formation", Journal of Accounting and Public Policy, Vol. 9 No. 1, pp. 19-36.

Braiotta, L. (1999), The Audit Committee Handbook, John Wiley \& Sons, New York, NY.

Carcello, J.V., Hermanson, D.R. and Raghunandan, K. (2005), "Factors associated with US public companies' investment in internal auditing”, Accounting Horizons, Vol. 19 No. 2, p. 69.

Carey, P., Simnett, R. and Tanewski, G. (2000), "Voluntary demand for internal and external auditing by family business", Auditing, Vol. 19 No. 1, p. 37.

Chow, C.W. (1982), "The demand for external auditing: size, debt and ownership influences", The Accounting Review, Vol. 57 No. 2, pp. 272-291.

Christ, M.H., Masli, A., Sharp, N.Y. and Wood, D.A. (2015), "Rotational internal audit programs and financial reporting quality: do compensating controls help?"', Accounting, Organizations and Society, Vol. 44, pp. 37-59.

Cohen, J., Krishnamoorthy, G. and Wright, A. (2004), "The corporate governance mosaic and financial reporting quality", Journal of Accounting Literature, Vol. 23, p. 87.

Collier, P. and Gregory, A. (1999), "Audit committee activity and agency costs", Journal of Accounting and Public Policy, Vol. 18 Nos 4/5, pp. 311-332.

Collis, J. (2010), "Audit exemption and the demand for voluntary audit: a comparative study of the UK and Denmark", International Journal of Auditing, Vol. 14 No. 2, pp. 211-231.

Coram, P., Ferguson, C. and Moroney, R. (2008), "Internal audit, alternative internal audit structures and the level of misappropriation of assets fraud”, Accounting \& Finance, Vol. 48 No. 4, pp. 543-559.

Davidson, R., Goodwin-Stewart, J. and Kent, P. (2005), "Internal governance structures and earnings management”, Accounting and Finance, Vol. 45 No. 2, pp. 241-267.

DeFond, M.L. (1992), "The association between changes in client firm agency costs and auditor switching", Auditing, Vol. 11 No. 1, p. 16.

DeZoort, F.T., Hermanson, D.R., Archambeault, D.S. and Reed, S.A. (2002), “Audit committee effectiveness: a synthesis of the empirical audit committee literature", Journal of Accounting Literature, Vol. 21, p. 38. 
Ettredge, M., Reed, M. and Stone, M. (2000), “An examination of substitution among monitoring devices: the case of internal and external audit expenditures", Review of Quantitative Finance and Accounting, Vol. 15 No. 1, p. 57.

Ettredge, M., Simon, D., Smith, D. and Stone, M. (1994), "Why do companies purchase timely quarterly reviews?", Journal of Accounting and Economics, Vol. 18 No. 2, pp. 131-155.

Fama, E.F. (1980), "Agency problems and the theory of the firm", The Journal of Political Economy, Vol. 88 No. 2, pp. 288-307.

Fama, E.F. and Jensen, M.C. (1983), "Separation of ownership and control", Journal of Law and Economics, Vol. 26 No. 2, pp. 301-325.

Felix, W.L., Jr, Gramling, A.A. and Maletta, M.J. (2001), "The contribution of internal audit as a determinant of external audit fees and factors influencing this contribution", Journal of Accounting Research, Vol. 39 No. 3, pp. 513-534.

Field, A. (2009), Discovering Statistics Using SPSS, SAGE Publications, London.

Financial Reporting Council (2008), "The combined code on corporate governance", available at: www.frc. org.uk/documents/pagemanager/frc/Combined_Code_June_2008/Combined $\% 20$ Code $\% 20 \mathrm{Web} \% 20$ Optimized\%20June \%202008\%282\%29.pdf, www.frc.org.uk/corporate/ukcgcode.cfm

Francis, J.R. and Stokes, D.J. (1986), "Audit prices, product differentiation and scale economies: further evidence from the Australian market”, Journal of Accounting Research, Vol. 24 No. 2, pp. 283-293.

Francis, J.R. and Wilson, E.R. (1988), "Auditor changes: a joint test of theories relating to agency costs and auditor differentiation", The Accounting Review, Vol. 63 No. 4, pp. 663-682.

Godfrey, J., Hodgson, A. and Holmes, S. (2003), Accounting Theory, John Wiley and Sons, Milton.

Goodwin-Stewart, J. and Kent, P. (2006a), "The use of internal audit by Australian companies", Managerial Auditing Journal, Vol. 21 Nos 1/2, p. 81.

Goodwin-Stewart, J. and Kent, P. (2006b), "Relation between external audit fees, audit committee characteristics and internal audit", Accounting \& Finance, Vol. 46 No. 3, pp. 387-404.

Gramling, A.A., Maletta, M.J., Schneider, A. and Church, B.K. (2004), "The role of the internal audit function in corporate governance: a synthesis of the extant internal auditing literature and directions for future research", Journal of Accounting Literature, Vol. 23 No. 1, p. 194.

Hass, S., Abdolmohammadi, M.J. and Burnaby, P. (2006), "The Americas literature review on internal auditing", Managerial Auditing Journal, Vol. 21 No. 8, p. 835.

Hay, D. and Davis, D. (2004), "The voluntary choice of an auditor of any level of quality", Auditing, Vol. 23 No. 2, p. 37.

Jensen, M.C. and Meckling, W.H. (1976), “Theory of the firm: managerial behavior, agency costs and ownership structure", Journal of Financial Economics, Vol. 3 No. 4, pp. 305-360.

Klein, A. (2002), "Economic determinants of audit committee independence", The Accounting Review, Vol. 77 No. 2, p. 435.

Knechel, W.R. and Willekens, M. (2006), "The role of risk management and governance in determining audit demand”, Journal of Business Finance \& Accounting, Vol. 33 Nos 9/10, pp. 1344-1367.

Lewington, D. (1996), “2020 Vision”, Managerial Auditing Journal, Vol. 11 No. 7, p. 3.

Mallin, C., Mullineux, A. and Wihlborg, C. (2005), "The financial sector and corporate governance: the UK case”, Corporate Governance: An International Review, Vol. 13 No. 4, pp. 532-541.

Mangena, M. and Tauringana, V. (2008), "Audit committees and voluntary external auditor involvement in UK interim reporting”, International Journal of Auditing, Vol. 12 No. 1, pp. 45-63.

Menon, K. and Deahl Williams, J. (1994), "The use of audit committees for monitoring", Journal of Accounting and Public Policy, Vol. 13 No. 2, pp. 121-139. 
MAJ

33,3

Meyer, J. and Rowan, B. (1977), "Institutionalized organisations: formal structure as myth and ceremony", American Journal of Sociology, Vol. 83 No. 2, pp. 340-363.

Moll, J., Burns, J. and Major, M. (2006), "Chapter 10: institutional theory", in Hoque, Z. (Ed.), Methodolical Issues in Accounting Research: Theories and Methods, Spiramus Press, London, pp. 183-205.

NYSE (2009), "Listed company manual”, available at: http:/nysemanual.nyse.com/LCM/Sections/

O'Sullivan, N. (2000), "The impact of board composition and ownership on audit quality: evidence from large UK companies", The British Accounting Review, Vol. 32 No. 4, pp. 397-414.

Paape, L., Scheffe, J. and Snoep, P. (2003), “The relationship between the internal audit function and corporate governance in the EU - a survey", International Journal of Auditing, Vol. 7 No. 3, pp. 247-262.

Pallant, J. (2007), SPSS Survival Manual: A Step by Step Guide to Data Analysis Using SPSS for Windows, Open University Press, London.

Prawitt, D., Smith, J. and Wood, D. (2009), "Internal audit quality and earnings management", The Accounting Review, Vol. 84 No. 4, p. 1255.

Sarens, G. (2009), "Internal auditing research: where are we going? Editorial", International Journal of Auditing, Vol. 13 No. 1, p. 1.

Sarens, G. and Abdolmohammadi, M.J. (2011), "Monitoring effects of the internal audit function: agency theory versus other explanatory variables", International Journal of Auditing, Vol. 15 No. 1, pp. 1-20.

Sarens, G. and De Beelde, I. (2006), "Internal auditors' perception about their role in risk management: a comparison between US and Belgian companies", Managerial Auditing Journal, Vol. 21 No. 1, p. 63.

Sarens, G., De Beelde, I. and Everaert, P. (2009), "Internal audit: a comfort provider to the audit committee", The British Accounting Review, Vol. 41 No. 2, pp. 90-106.

Scarbrough, D.P., Rama, D.V. and Raghunandan, K. (1998), "Audit committee composition and interaction with internal auditing: Canadian evidence”, Accounting Horizons, Vol. 12 No. 1, p. 51.

Selim, G., Woodward, S. and Allegrini, M. (2009), "Internal auditing and consulting practice: a comparison between UK/Ireland and Italy”, International Journal of Auditing, Vol. 13 No. 1, pp. 9-25.

Sherer, M. and Kent, D. (1983), Auditing and Accountability, Pitman, London.

Short, H. and Keasey, K. (1999), "Managerial ownership and the performance of firms: evidence from the UK", Journal of Corporate Finance, Vol. 5 No. 1, pp. 79-101.

Simunic, D.A. (1980), "The pricing of audit services: theory and evidence", Journal of Accounting Research, Vol. 18 No. 1, pp. 161-190.

Spira, L.F. and Page, M. (2003), "Risk management: the reinvention of internal control and the changing role of internal audit", Accounting, Auditing \& Accountability Journal, Vol. 16 No. 4, p. 640.

Spraakman, G. (1997), "Transaction cost economics: a theory for internal audit?", Managerial Auditing Journal, Vol. 12 No. 7, p. 323.

Subramaniam, N. (2006), "Chapter 5: agency theory and accounting research: an overview of some conceptual and empirical issues", in Hoque, Z. (Ed.), Methodological Issues in Accounting Research: Theories and Methods, Spiramus Press, London, pp. 55-81.

Tauringana, V. and Clarke, S. (2000), "The demand for external auditing: managerial share ownership, size, gearing and liquidity influences", Managerial Auditing Journal, Vol. 15 No. 4, p. 160.

The Institute of Internal Auditors (2010a), "International professional practices framework (IPPF)", available at: www.theiia.org/guidance/standards-and-guidance/, https://na.theiia.org/standardsguidance/mandatory-guidance/Pages/Definition-of-Internal-Auditing.aspx 
The Institute of Internal Auditors (2010b), "International standards for the professional practice of internal auditing (standards)", available at: www.theiia.org/guidance/standards-and-guidance/ ippf/standards/

Wallace, W.A. (1984), "Internal auditors can cut outside CPA costs", Harvard Business Review, Vol. 62

Voluntary use of internal audit No. 2, pp. 16-20.

Wallace, W.A. and Kreutzfeldt, R.W. (1991), "Distinctive characteristics of entities with an internal audit department and the association of the quality of such departments with errors", Contemporary Accounting Research, Vol. 7 No. 2, pp. 485-512.

Williamson, O.E. (1975), Markets and Hierarchies, Free Press, New York, NY.

Williamson, O.E. (1985), The Economic Institutions of Capitalism, Free Press, New York, NY.

Zaman, M., Hudaib, M. and Haniffa, R. (2011), "Corporate governance quality, audit fees and non-audit services fees", Journal of Business Finance \& Accounting, Vol. 38 Nos 1/2, pp. 165-197.

\section{Further reading}

Christopher, J., Sarens, G. and Leung, P. (2009), "A critical analysis of the independence of the internal audit function: evidence from Australia”, Accounting, Auditing \& Accountability Journal, Vol. 22 No. 2, pp. 200-220.

Ramamoorti, S. (2003), "Chapter 1: internal auditing: history, evolution and prospects", in Bailey, A.D., Gramling, A.A. and Ramamoorti, S. (Eds), Research Opportunities in Internal Auditing, The Institute of Internal Auditors, Altamonte Springs, FL, pp. 1-23.

Ruud, T.F. (2003), "Chapter 3: the internal audit function: an integral part of organizational governance", in Bailey, A.D., Gramling, A.A. and Ramamoorti, S. (Eds), Research Opportunities in Internal Auditing, The Institute of Internal Auditors Research Foundation, Altamonte Springs, FL, pp. 73-96.

\section{Corresponding author}

Hazem Ramadan Ismael can be contacted at: hazem.ismael@qu.edu.qa

For instructions on how to order reprints of this article, please visit our website: www.emeraldgrouppublishing.com/licensing/reprints.htm Or contact us for further details: permissions@emeraldinsight.com 